\title{
APLICAÇÃO DO CLORETO DE BENZALCÔNIO EM CENTRO CIRÚRGICO: ALGUMAS EXPERIÊNCIAS EM LABORATÓRIO
}

\author{
* Terezinha Costa Carvalho Parlato \\ * Larceny Moreira Vital
}

\section{INTRODUÇÃO:}

Por ocasião do I Encontro de Enfermeiras de Centro Cirúrgico, realizado durante a Semana da Enfermagem, em 1969, no auditório da Johnson \& Johnson do Brasil (em São Paulo), assistimos a palestras que versaram sobre esterilização física e química.

Tornou-se evidente a divergência de opiniões sôbre o uso de agentes químicos, métodos e técnicas empregadas em diversos hospitais. Sentimos nessa ocasião a necessidade de conhecer a atuação dessas diferentes classes de substâncias químicas, citadas na tabela de Spaulding, que as diferencia por niveis de desinfetantes, e que eram usados no Hospital das Clínicas. Em vista dessas palestras, o Serviço de Enfermagem do Hospital das Clínicas da Faculdade de Medicina da Universidade de São Paulo, em contato com o Departamento de Biologia da Johnson \& Johnson, providenciou um estágio para enfermeiras nesse Departamento. A fim de atender a esta atividade, foram designadas pela Diretoria do Serviço de Enfermagem duas enfermeiras das Unidades de Enfermagem e uma de Centro Cirúrgico.

No início o estágio consistiu em práticas e técnicas microbiológicas, que teve por finalidade nos familiarizar com os métodos empregados por aquele Departamento, o que nos possibilitou iniciar um trabalho de pesquisa experimental.

Face à incidência de infecções cruzadas nos hospitais, ressaltamos por intermédio deste trabalho o uso seguro e adequado

* Enfermeira de Centro Cirúrgico do Hospital das Clínicas da Faculdade de Medicina da Universidade de São Paulo.

** Enfermeira de Clínica Cirúrgica do Hospital das Clínicas da Faculdade de Medicina da Universidade de São Paulo. 
de agentes químicos que deveriam ser empregados como desinfetantes, antisséticos e esterilizantes.

Tratando-se de agentes químicos em uso num grande hospital, como é o Hospital das Clínicas da Universidade de São Paulo, onde a maioria dos produtos são preparados, na Seção de Química Industrial, existe a fácil aquisição dos mesmos e consequentemente, isto dificulta a escolha adequada para uma determinada aplicação.

Baseados em dados laboratoriais obtidos em pesquisas bibliográficas, poderiamos concluir como deveriam ser aplicadas estas substâncias e como são limitadas suas atividades sôbre os microorganismos. Contudo, resultados laboratoriais incompletos, ocasionariam interpretações precipitadas, não concluindo sôbre as atividades anti-microbianas, isto é, bactericida ou bacteriostática.

Chamamos a atenção para êsse aspecto, pois podemos ficar confundidos arite o aparecimento de tantos agentes químicos, cujo nome comercial e apresentação, muitas vezes não nos convence. Desnecessário se torna para nossos propósitos, nos alongarmos neste aspecto, pois os testes bacteriológicos por nós realizados confirmam o que descrevemos anteriormente.

O presente trabalho tem por finalidade esclarecer estas dúvidas e também aprimorar técnicas, que certamente virão benefi. ciar as atividades nos mais diversos setores dos hospitais.

Dos vários agentes químicos testados, como sejam: T'ego (r), Germekil (r1), Oxianeto de Mercúrio (r2), Cidex (r3) e outros, escolhemos para o presente estudo um composto quaternário de amônia, o Cloreto de Benzalcônio.

\section{OBJETIVOS DO TRABALHO:}

Inảagávamos há um ano atrás: será o Cloreto de Benzalcônio um agente químico esterilizante? Poderemos continuar a usá-lo com esta finalidade?

$\mathrm{Na}$ sequência deste trabalho, procuramos afirmar conclusivamente ,em concordância com os mais diversos autores, entre estes Spaulding, quanto ao emprego de produtos desta classe (Compostos quaternários de amônia).

(r) Tego - T. H. Goldschmit-A-G, Essen/Alemanha

(r1) Germekil - Laboratório Darrow

(r2) Oxianeto de Mercúrio - Henry Farma Produtos Químicos

(r3) Cidex - Divisão Ethicon, Johnson \& Johnson 


\section{CONSIDERAÇõeS SôBRE COMPOSTOS QUATERNÁRIOS DE AMôNIA :}

\subsection{Agentes ativos de superfície:}

São substâncias que modificam a tensão superficial, influenciando, portanto, no grau de dispersão, a difusão, a umectação, embebição ou a penetração, assim como a forma de líquidos que são colocados em contato com outros líquidos, destes com sólidos ou com gases.

Eles precipitam, desnaturam ou formam complexos com proteinas, podendo exercer atividades citolíticas, bactericida, etc...

São classificados como: Aniônicos, Catiônicos e Não Iônicos, conforme variação da atividade enccntrada nos sais que têm um ion de maior pêso molecular que outro, em relação com os complexos ionizados formados entre agentes químicos e microoorganismos.

\section{A. Compostos aniônicos:}

Contém uma parte hidrofóbica (oleosolúvel). Pertencem a êsse grupo: sal doméstico, louril-sulfato sódico, amidas sulfatadas e outros. A intensidade de ação aumenta quando o $\mathrm{pH}$ baixa.

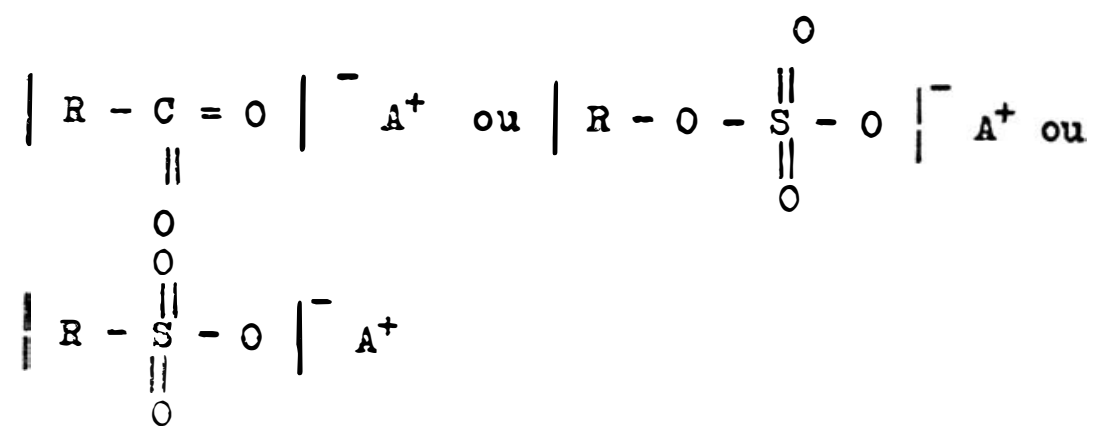

B. Compostos catiônicos:

Contém o grupo hidrofóbico, porém possuem um grupo hidrofílico carregado positivamente, podendo ser um composto quaternário de amônia (cloreto de benzalcô- 
nio), ou antibiótico polipeptídicos, (tirotricina, gramicidina).

A intensidade de ação aumenta quando o pH se eleva.

$$
|R-|_{R_{3}}^{R_{2}}-\left.R_{2}\right|^{*} x^{-}
$$

\section{Compostos não iônicos:}

Possuem a parte hidrofóbica equilibrada por um grupo hidrofílico, como o óxido de etileno polimerizado, ou um álcool poliídrico. Pertencem a esse grupo o Tween 80, um polioxialquil derivado do monooleato de Sorbitan e outros ésteres polioxietilênicos como o Triton WR 1339.

$$
\mathrm{R}-\mathrm{C}-\mathrm{C}-\underset{\mathrm{C}}{\mathrm{C}}-\underset{\mathrm{O}}{\mathrm{C}} \underset{\mathrm{O}}{\mathrm{C}}-\underset{\mathrm{OH}}{\mathrm{C}}-\mathrm{H}
$$

\subsection{Generalidades:}

Os compostos quaternários de amônia pertencem a uma classe especial de desinfetantes químicos caracterizados como um grupo de aminas que podem ser sintetizados para dar compostos de nitrogênio com o último radical tendo a valência 5 . São agentes catiônicos.

As aminas podem ser consideradas como substitutos das amônias; assim o amônio quaternário composto é considerado como substituto de sais de amônia.

Os compostos quaternários são preparados pela condensação de uma amina terciária e um sal alkil. A amina terciária pode ter uma variedade de alkil ou grupos de aril como substituindo para um átomo de hidrogênio da amônia ou ainda uma amina aromática semelhante a piridina. 
Portanto, o número de compostos que podem ser preparados é bastante elevado, porém, somente com valor desinfetante. Representa bem, como droga principal dêste grupo, o cloreto de benzalcônio (Zefiran*), usado nas soluções de $1 \%$ ou $10 \%$. Os agentes catiônicos agem rapidamente e não são praticamente irritantes: são queratolíticos e emulsionantes. Quando aplicado sôbre a pele, formam em geral uma película cuja face em contato com o tegumento tem fraco poder germicida.

Como catiônico, o cloreto de benzalcônio apresenta incompatibilidade com os agentes aniônicos, como os sabões. Relativamente atóxicos os compostos quaternários de amônia, quando aplicados sôbre a pele, embora a toxidade aguda e crônica quancso administrados por via oral a animais, seja baixa, o seu uso parenteral pode produzir ações sistêmicas graves. Deve-se, portanto, evitar seu emprego em lavagens de cavidades orgânicas.

Atuam mais sobre bactérias gram + e menos sobre gram -; embora tenham ação também sôbre fungos, protozoários e virus, não os matam, tampouco destroem esporos; não podem ser usados como esterilizantes.

\section{A. Mecanismo de ação:}

Parecem interferir com os mecanismos enzimáticos das bactérias. Suas atividades antibacterianas se devem a reativid.ade química e sua adsorvilidade. Os efeitos tóxicos dêsses agentes são devidos a sua ação química sôbre estruturas celulares, especialmente a membrana celular, impedindo o escoamento de constituintes citoplasmáticos para o exterior da célula, bem como, selecionam a entrada de nutrientes para o interior da mesma.

Assim, qualquer agente químico que danifique a membrana semi-permeável, por alteração de sua estrutura físico-química, tende a produzir uma desorganização geral da fisiologia celular.

B. Influência do ambiente químico:

Uma substância em geral, pode afetar os microorganismos da seguinte forma:

(*) Adsorção dos CQA - A propriedade de concentrar-se na superfície dá a êsses agentes seu quase único valor para desinfetante de superfície, para preparaçāo da pele no pré-operatório, etc... Os ions ativos são adsorvidos rapidamente. 

a) servindo como nutriente e assim possibilitando o seu crescimento;
b) impedindo o seu crescimento num meio - efeito bacteriostático;
c) produzindo morte do microorganismo - efeito bactericida.
C. Fatôres gerais que em conjunto afetam os componen- tes e o processo:
a) temperatura;
b) fenômenos de superfície, especialmente adsorção. tensão superficial, alterações de permeabilidace e difusão;
c) concentração hidrogeniônica;
d) presença de outros eletrólitos que influenciam a ionização do agente químico e as propriedades das células;
e) presença de substância orgânica, especialmente proteinas que podem reagir com a substância ou formar películas protetoras nos microorganismos reduzem em geral a ação do desinfentante;
f) pressão;
g) tempo.

\subsection{Cloreto de benzalcônio:}

Nome Registrado: Zefirol (*) e cloreto de Zefirol.

Inscrito na Farmacopéia Brasileira; mistura de cloreto de alquildimetilbenzilamônio em que o $\mathrm{R}$ da fórmula em geral representa uma mistura de alquilas. É um pó branco ou branco amarelado, amorfo ou em forma de massa gelatinosa de odor aromático, sabor amargo, muito solúvel em água, álcool e acetona, praticamente insolúvel no éter e levemente no benzeno.

Coeficiente fenólico: 300 .

No comércio apresenta-se nas formas de solução (aquosa) e tinturas (solução em álcool, água e acetona) a $1 \%$ e creme a 1:10.000.

Matérias primas para a sua preparação: metilbenzilamina e o Lorol ( álcool correspondente ao ácido láurico).

Mistura de álcoois obticlos por hidrogenação de ácidos graxos extraidos de gorduras vegetais, principalmente de

(*) Zafirol - Laboratório Bayer. 
coco. Trata-se o lorol com o cloreto de tionila e faz-se o cloreto de ácido resultante condensar com a metilbenzilamina; em seguida quarterniza-se o produto assim obtido com o cloreto de metila.

Devido a carga positiva do nitrogênio quaternário êsses compostos são incompativeis com substâncias como os sabões, sais aniônicos, geralmente formando compostos insolúveis.

A ação diminuidora da tensão superficial apenas atua facilitando as relações de contato com a superfície a desinfetar e não como agente bactericida. A ação antibacteriana é reduzida grandemente em presença de matéria orgânica (sôro, sangue, pús, etc...).

Uso: desinfecção da pele (campo operatório, pequenas ferid.as e escoriações), tratamento de processos infecciosos cutâneos, vaginais, oculares, vesicais. (Indicação do fabricante). Desinfecção de algum instrumental cirúrgico, sondas de borracha, máscaras, umidificadores, ou seja, objetos que somente entrem em contato com a pele intacta (Indicação de Spaulding).

\subsection{Relação de autores que efetuaram estudos relativos aos compostos quaternários de amônia:}

3.4.1. Einhorn - 1905. Uso como antisséptico: desinfecção cirúrgica e geral.

3.4.2. Kahn - 1911. Reycheer - 1913. Síntese e referências limitadas a atividade antimicrobiana dos compostos quaternários de amônia.

3.4.3. Wetzel - 1935 -.- Uso na limpeza cirúrgica das mãos estudo de um dos compostos superior ao uso do álcool;

3.4.4. Schmidt - 1935. Caesar, 1935, Seeman - 1935, Rodercurt - 1934, descreveram o sucesso do uso dessas soluções em Ginecologia e instrumental cirúrgico;

3.4.5. Heineman e outros (1937, atividade sôbre fungos ( fungicida); Dunn (1936), atividade contra uma variedade de fungos;

3.4.6. Fair e colaboradores (1945), Kessel e Moore (1946) destruição de cistos de Entamoeba histolystica; Johnson e Trussel (1943), Quisno e Foter (1946), atuação nas Trichomonas vaginais; Morgan Campbel (1946), Lawrence (1946), destruição da Tr. foetus; 
3.4.7. Hotchkiss (1946), desprendimento de N e P da célula; Galton (1951), cesprendimentos: constituintes da célula e que parte da ação germicida devido a ação tardia dos CQA;

3.4.8. Lawrence (1950), Glassmann (1948), revisão dêsses compostos considerando propriedades químicas, físicas, biológicas e aplicação como antisséptico;

3.4.9. Tamasik (1955), danificação e desnaturação da membrana citoplasmática e citoplasma das células bacterianas, pelo composto;

3.4.10. Dawson e alli (1953), microscópio eletrônico efeito sôbre Staphilococus Aureus: ação na célula e membrana;

3.4.11. Kundsin (1960), Halacka e Neswal (1962), citam uso como agente antimicrobiano, porém pouco usado e conhecido;

3.4.12. D'Arcy e Taylor (1962), atividades farmacodinâmicas, bloqueador de agentes iônicos e propriedades antimicrobianas;

3.4.13. Klein e De Forest (1963, 1965), Cloreto Benzalcônio $1 \%$ : inativou viroses lipofílicas: Herpes simples, vaccénia, Ásia - tipo influenza e Adenovírus;

3.4.14. Arostrong e Froelich (1964), Cloreto de Benzalcônio, inativa, virus da influenza, sarampo, hidrofobia, varíola.

\section{MÉTODOS BACTERIOLÓGICOS EMPREGADOS:}

\subsection{Microorganismos:}

Os bastonetes esporulados dividem-se habitualmente em dois gêneros:

- o gênero Bacilus que consiste em aeróbios estritos e anaeróbios facultativos;

- o gênero Clostridium, que consiste em anaeróbios estritos. Não somente são incapazes de crescer em presença de oxigênio livre, como também, êste elemento lhes é altamente tóxico, exceto quando estão no estado de esporos.

4.1.1. Bacilo Subtilis - Aeróbio esporogênico - Gram-positivo. Bastonetes retos de 2 a 8 micra de comprimento por 0,7 micra de largura. Os esporos estão situados mais próximos a uma das extremidades. 
Formam cadeias longas e os esporos só existem nestas cadeias.

4.1.2. Clostridium Sporogenes: descrito definitivamente por Metchnikoff em 1908. E um bacilo anaeróbio, gram-positivo muito móvel, formando esporos ovais subterminais;

4.1.3. Stafilococus Aureus: é um coco esférico cujo diâmetro médio é 0,8 micra. Gram-positivo, podendo ocorrer, no meio dos cachos algumas formas gramnegativas. Não formam cápsulas nem esporos.

Devido a frequência e importância dos estafilococos nas infecções piogênicas, traumáticas e cirúrgicas, foi utilizado em nossos testes.

4.1.4. Escherichia coli:: bastonetes gram-negativos de 2 a 3 micra de comprimento por 0,6 micra de largura apresentando ocasionalmente formas filamentosas.

\subsection{Método bacteriológico padrão:}

Prova para determinar a ação esporicida: (A.O.A.C. 1966) * Esste método se aplica a desinfetantes ou esterilizantes líquidos ou gasosos, miscíveis em água para determinar a presença ou ausência de atividade esporicida.

Os testes cujos resultados iremos apresentar foram efetuados nas concentrações mais usadas e estão classificados conforme quadro abaixo.

Outros testes foram realizados, porém omitidos dêste trabalho, devido ao seu pequeno valor.

\section{CONCENTRAÇÃO E NÚMERO DE PROVAS EFETUADAS}

\begin{tabular}{lcc}
\hline CLORETO DE & NÚMERO DE PROVAS & TABELAS \\
BENZALCONIO & EFETUADAS & \\
\hline $1 / 1000$ & 1 & $\mathrm{~A}$ \\
$1 / 100$ & 5 & $\mathrm{~B}$ \\
$5 / 100$ & 2 & $\mathrm{C}$ \\
Cl. Benz. flui- & 2 & D e D' \\
dos biológicos & & \\
Cl. Benz. Neu- & 3 & $\mathrm{E}$ \\
tralizante & & \\
\hline
\end{tabular}

(*) Official Methods of analysis of the association of official agricultural Chemists. 


\section{MÉTOdOS DE DETERMINAC̣ãO DE AC̣ãO ESPORICIDA:}

5.1. Descrição do método para testar a ação esporicida do cloreto de Benzalcônio a 1\%/00:

\subsubsection{Finalidade:}

Êste método foi elaborado para testar a ação do cloreto de Benzalcônio contra esporos bacterianos.

\subsubsection{Microorganismos e meio de cultura:}

A. Microorganismos usados:

Clostridium Sporogenes

Bacilus Subtilis

B. Meios de cultura:

Eugon Broth (Difco)

Fluid Thioglicolate Medium (Difco)

\subsubsection{Material necessário:}

- Tubos de pirex 25x200mm.

- Placas de Petri $15 \times 20 \mathrm{~mm}$. forradas com papel de filtro.

- Pipetas de $10 \mathrm{ml}$.

- Alça de platina e gancho (alça de $4 \mathrm{~mm}$. de diâmetro).

- Estantes - Solução cie cloreto de Benzalcônio.

- Banho-maria.

- Alças de sutura - Alças padronizadas (3 vol_ tas de fio de sêda n. ${ }^{\circ} 3$, equivalente, a $21 / 2$ polegadas). Estas alças são colocadas em placas de Petri e esterilizadas a $121^{\circ} \mathrm{C} 15 \mathrm{lb}$. por 30 minutos.

5.1.4. Desenvolvimento do Teste $-1 .^{\mathrm{a}}$ Fase:

- Em 2 tubos 25x200mm. contendo $35 \mathrm{ml}$. de meio de cultura Eugon Broth e Thioglicolate Medium, inocular uma alçada de Bacilus Subtilis e Clostridium Sporogenes.

- Incubar por 72 horas a $37^{\circ} \mathrm{C}$.

- Após êsse período de incubação. aquecer os tubos a $80^{\circ} \mathrm{C}$ durante 10 minutos a fim de serem eliminadas as formas vegetativas esporuladas menos resistentes.

- Colocar 5 alças de sutura em cada tubo contendo os esporos e esperar 15 minutos. Após êsse periodo de contato, retirar as alças com auxílio de um gancho e colocá-las em placas de Petri, estéreis, forradas com papel filtro. 
Deixar secar à temperatura ambiente, durante 22 a 26 horas.

\subsubsection{Desenvolvimento do Teste $-2 .^{\mathrm{a}}$ Fase:}

- Colocar $10 \mathrm{ml}$. de cloreto de Benzalcônio $1 \%$ em 2 tubos de $25 \times 200 \mathrm{~mm}$.

- Das alças de sutura (5) de cada microorganismo, colocar uma no meio de cultura, (Thioglicolate Medium) e uma no meio de cultura Eugon Broth, para controle.

- As 8 alças restantes colocar em contato com o cloreto de Benzalcônio.

- Após 10, 30, 1 hora e 2 horas de contato com o agente químico em teste, transferir as alças para os respectivos meios de cultura Thioglicolate Medium e Eugon Broth.

- Incubar por uma semana a $37^{\circ} \mathrm{C}$.

- Os tubos controle devem apresentar abundante crescimento.

\subsubsection{Contra Prova:}

- Dos tubos que apresentam ausência de crescimento, transferir as alças de sutura para um nôvo tubo com meio de cultura.

- No tubo em que houve ausência de crescimento e do qual foi retirada a alça de sutura, inocular uma alçacia do tubo controle.

\subsubsection{Como interpretar os resultados:}

A. Ação esporicida. São indispensáveis 3 condições:

- ausência de crescimento no tubo contendo alça de sutura;

- ausência de crescimento no tubo para o qual foi transferida a alça de sutura;

- presença de crescimento no tubo a, após ser reinoculado uma alçada do tubo controle.

B. Ação bacteriostática. São indispensáveis 3 condições:

- ausência de crescimento no tubo contendo meio de sutura e alça de sutura:

- presença de crescimento no tubo ao qual foi transferida a alça de sutura;

- ausência ou presença de crescimento no tubo 
após ser reinoculado com uma alçada de tubo controle.

Quando houver ausência de crescimento pode-se concluir presença de ação inibidora do cloreto de Benzalcônio.

Quando houver presença de crescimento, pode-se concluir que o meio de cultura exerceu ação inativadora sobre o cloreto de Benzalcônio ou então a concentração residual do referido agente não foi suficiente para exercer qualquer atividade sobre o microorganismo.

Ação esporicida do cloreto de Benzalcônio a $1 \%$

\begin{tabular}{|c|c|c|c|c|c|c|c|c|}
\hline \multirow{2}{*}{$\begin{array}{c}\text { Tempo de } \\
\text { contato }\end{array}$} & \multicolumn{2}{|l|}{$1 .^{2}$} & \multicolumn{2}{|c|}{$\begin{array}{l}\text { Contra } \\
\text { prova }\end{array}$} & \multicolumn{2}{|c|}{ 2.2 prova } & \multicolumn{2}{|c|}{$\begin{array}{c}\text { Contra } \\
\text { prova }\end{array}$} \\
\hline & Cl. Sp. & B. S. & Cl. Sp. & B. S. & Cl. Sp. & B. S. & Cl. SP. & B. S. \\
\hline $10 \mathrm{~min}$. & + & - & + & - & + & - & + & - \\
\hline $30 \mathrm{~min}$. & + & - & + & - & + & - & + & - \\
\hline 1 hora & + & - & + & - & + & - & + & - \\
\hline 2 horas & + & - & + & - & + & - & + & - \\
\hline
\end{tabular}

$(+)=$ crescimento

(一) = ausência de crescimento

NOTA: Os mesmos testes foram efetuados para verificação da ação esporicida do cloreto de Benzalcônio, em concentrações dife_ rentes. As tabelas $\mathbf{B}$ e $\mathbf{C}$ indicam esses resultados.

Ação esporicida do cloreto de Benzalcônio a $1 \%$

\begin{tabular}{|c|c|c|c|c|c|c|c|c|}
\hline \multirow[t]{2}{*}{$\begin{array}{l}\text { Tempo de } \\
\text { contato }\end{array}$} & \multicolumn{2}{|c|}{$1^{a}$ prova } & \multicolumn{2}{|c|}{$\begin{array}{l}\text { Contra } \\
\text { prova }\end{array}$} & \multicolumn{2}{|c|}{ 2. ${ }^{a}$ prova } & \multicolumn{2}{|c|}{$\begin{array}{c}\text { Contra } \\
\text { prova }\end{array}$} \\
\hline & Cl. Sp. & B. S. & Cl. Sp. & B. S. & Cl. Sp. & B. $\mathbf{S}$. & Cl. SP. & B. S. \\
\hline $10 \mathrm{~min}$ & + & - & + & - & + & - & + & - \\
\hline $30 \mathrm{~min}$ & + & - & + & - & + & - & + & - \\
\hline 1 hora & + & - & + & - & + & - & + & - \\
\hline 2 horas & + & - & + & - & + & - & + & - \\
\hline
\end{tabular}

$(+)=$ crescimento

(一) = ausência de crescimento 
Ação esporicida do cloreto de Benzalcônio a 5\%

\begin{tabular}{|c|c|c|c|c|c|c|c|c|}
\hline \multirow[t]{2}{*}{$\begin{array}{l}\text { Tempo de } \\
\text { contato }\end{array}$} & \multicolumn{2}{|c|}{$1 .^{a}$ prova } & \multicolumn{2}{|c|}{$\begin{array}{c}\text { Contra } \\
\text { prova }\end{array}$} & \multicolumn{2}{|c|}{ 2. ${ }^{\mathrm{a}}$ prova } & \multicolumn{2}{|c|}{$\begin{array}{c}\text { Contra } \\
\text { prova }\end{array}$} \\
\hline & Cl. Sp. & B. S. & Cl. Sp. & B. S. & Cl.Sp. & B. S. & Cl. SP. & B. S. \\
\hline $10 \mathrm{~min}$. & - & - & - & - & - & . - & - & - \\
\hline $30 \mathrm{~min}$. & - & - & - & - & - & - & - & - \\
\hline 1 hora & - & - & - & - & - & - & - & - \\
\hline 2 horas & - & - & - & - & - & - & - & - \\
\hline
\end{tabular}

(一) = ausência de crescimento

\subsection{Cloreto de Benzalcônio a 1\% + Neutralizante Tween 80:}

\subsubsection{Finalidade:}

Este método foi elaborado para neutralizar a ação re_ sidual do cloreto de Benzalcônio, sobre os microorganismos em teste.

5.2.2. Microorganismo e meio de cultura:

A. Microorganismos usados:

- Clostridium Sporogenes Bacilus Subtilis

B. Meios de cultura:

- Eugon Broth (Difco)

- Fluid Thioglicolate Medium (Difco)

\subsubsection{Material necessário:}

- 4 tubos $25 \times 200 \mathrm{~mm}$.

- 12 tubos contendo meio de cultura.

- 3 erlenmayer

- 2 placas de Petri

- alça die platina e gancho

- alça cle sutura

- solução neutralizante Tween 80

- solução de cloreto de Benzalcônio 1\%

5.2.4. Desenvolvimento do Teste $-1 .^{\mathrm{a}}$ Fase:

- Colocal $5 \mathrm{ml}$. de Tween $+1,0 \mathrm{~g}$. de Thioglicolato de sódio em 1 erlenmayer e completar com água distilada estéril até atingir $100 \mathrm{ml}$.. Esterilizar esta solução a $121^{\circ} \mathrm{C}$ durante 15 minutos.

- Colocar $9 \mathrm{ml}$. desta solução em um tubo e $10 \mathrm{ml}$. da solução de cloreto de Benzalcônio $1 \%$ em 2 tubos. 
- Passar as 8 alças contaminadas com esporos das placas de Petri para os tubos contendo solução de cloreto de Benzalcônio.

Após 10' de contato transferir as alças para o tubo contendo a solução neutralizante. Após 10', 30', 1 h e $2 \mathrm{~h}$ de contato com a solução neutralizante, transferir as alças para os meios de cultura.

5.2.5. Desenvolvimento do Teste - 2. ${ }^{\mathrm{a}}$ Fase (viabilidade do meio de cultura):

- Passar as alças contaminadas com esporos para os meios de cultura.

- Teste de neutralizante (ação bactericida ou bacteriostática).

- Deixar 2 alças contaminadas com esporos em contato com a solução neutralizante durante 2 horas; após, transferir para os meios de cultura.

- Incubar por uma semana a $37^{\circ} \mathrm{C}$.

Ação esporicida do cloreto de Benzalcônio

a $1 \%$ com neutralizante $(++)$

\begin{tabular}{|c|c|c|c|c|c|c|c|c|}
\hline \multirow[t]{2}{*}{$\begin{array}{l}\text { Tempo de } \\
\text { contato }\end{array}$} & \multicolumn{2}{|c|}{$1 .^{a}$ prova } & \multicolumn{2}{|c|}{$\begin{array}{l}\text { Contra } \\
\text { prova }\end{array}$} & \multicolumn{2}{|c|}{$2^{a}$ prova } & \multicolumn{2}{|c|}{$\begin{array}{c}\text { Contra } \\
\text { prova }\end{array}$} \\
\hline & Cl.Sp. & B. S. & Cl. Sp. & B. S. & Cl.Sp. & B. S. & Cl. SP. & B. S. \\
\hline $10 \mathrm{~min}$ & + & - & + & - & + & - & + & - \\
\hline $30 \mathrm{~min}$ & + & - & + & - & + & - & + & - \\
\hline 1 hora & + & - & + & - & + & - & + & - \\
\hline 2 horas & + & - & + & - & + & - & + & - \\
\hline
\end{tabular}

$(+)=$ crescimento

(一) = ausência de crescimento

$(++)$ Tween

\subsection{Cloreto de Benzalcônio a $1 \%$ + neutralizante (Duponol C):}

\subsubsection{Finalidade:}

Em vista do resultado obtido com o neutralizante T'ween 80 não ter sido satisfatório, o mesmo teste foi repetido com Duponol $\mathbf{C}$ na concentração idêntica ao cloreto de benzalcônio, isto é, $1 \%$, e com Duponol C a 2,5\%, ampliando-se a faixa dos tempos de contato. 
Ação esporicida do cloreto de Benzalcônio

a $1 \%$ com neutralizante $(t+)$

\begin{tabular}{|c|c|c|c|c|c|c|c|c|}
\hline \multirow[t]{2}{*}{$\begin{array}{l}\text { Tempo de } \\
\text { contato }\end{array}$} & \multicolumn{2}{|c|}{ 1.2 prova } & \multicolumn{2}{|c|}{$\begin{array}{c}\text { Contra } \\
\text { prova }\end{array}$} & \multicolumn{2}{|c|}{ 2.2 prova } & \multicolumn{2}{|c|}{$\begin{array}{c}\text { Contra } \\
\text { prova }\end{array}$} \\
\hline & Cl. Sp. & B.S. & Cl. Sp. & B. S. & Cl. Sp. & B. S. & Cl. SP. & B. S. \\
\hline $10 \mathrm{~min}$. & + & - & + & - & + & - & + & - \\
\hline $20 \mathrm{~min}$. & + & - & + & - & + & - & + & - \\
\hline $30 \mathrm{~min}$. & + & - & + & - & + & - & + & - \\
\hline 1 hora & + & - & + & - & + & - & + & - \\
\hline 1:30 hs. & - & - & + & - & + & - & + & - \\
\hline 2 horas & - & - & + & - & + & - & + & - \\
\hline
\end{tabular}

$(++)$ Duponol C $1 \%$

Ação esporicida do cloreto de Benzalcônio

a $1 \%$ com neutralizante $(++)$

\begin{tabular}{|c|c|c|c|c|c|c|c|c|}
\hline \multirow[t]{2}{*}{$\begin{array}{l}\text { Tempo de } \\
\text { contato }\end{array}$} & \multicolumn{2}{|c|}{$1 .^{a}$ prova } & \multicolumn{2}{|c|}{$\begin{array}{c}\text { Contra } \\
\text { prova }\end{array}$} & \multicolumn{2}{|c|}{ 2. ${ }^{\mathrm{a}}$ prova } & \multicolumn{2}{|c|}{$\begin{array}{c}\text { Contra } \\
\text { prova }\end{array}$} \\
\hline & Cl. Sp. & B. S. & Cl. Sp. & B. S. & Cl. Sp. & B. S. & Cl. SP. & B. S. \\
\hline $10 \mathrm{~min}$. & + & - & + & - & + & - & + & - \\
\hline $20 \mathrm{~min}$. & + & - & + & - & + & - & + & - \\
\hline $30 \mathrm{~min}$. & + & - & + & - & + & - & + & - \\
\hline 1 hora & + & - & + & - & + & - & + & - \\
\hline 1:30 hs. & + & - & + & - & + & - & + & - \\
\hline 2 horas & + & - & + & - & + & - & + & - \\
\hline
\end{tabular}

$(++)$ Duponol C $2,5 \%$

6. MÉTOdoS DE DETERMINAÇÃo DE AÇÃO BACTERICIDA:

6.1. Cloreto de Benzalcônio a $1 \%$ em presença de fluidos biológicos:

6.1.1. Finalidade:

Este método foi elaborado para testar a ação do cloreto de Benzalcônio em presença de fluidos biológicos (sôro humano). 


\subsubsection{Microorganismos usados e meio de cultura:}

A. Microorganismos:

- Escherichia Coli - 1133

- Stafilococos Aureus - 209 (1209)

B. Meios de cultura:

- Bacto Penassay

- Brain Heart Infusion

\subsubsection{Material necessário:}

- 1 pipeta de $10 \mathrm{ml}$.

- 1 pipeta de $1 \mathrm{ml}$.

- 1 alça de platina

- 10 tubos de $25 \times 200 \mathrm{~mm}$.

- 8 tubos c/ meio de cultura

- 2 estantes

- sôro humano (filtrado em membrana Millig G.S.)

\subsubsection{Preparo do Inoculum:}

Preparar uma suspensão de uma cultura de 24 horas de Escherichia Coli e Stafilococos Aureus, com $10 \mathrm{ml}$. de solução salina. Pipetar $1 \mathrm{ml}$. dessa suspensão e transferir para $9 \mathrm{ml}$. de solução salina. Em seguida transferir para o meio de cultura Bacto Penassay e Brain Heart Infusion, na proporção de $1 / 100$. Vazar $20 \mathrm{ml}$. do meio inoculado para as placas de Petri e deixar solidificar.

\subsubsection{Desenvolvimento do Teste:}

- colocar em 2 tubos $9 \mathrm{ml}$. de cloreto de Benzalcônio a $1 \%+1 \mathrm{ml}$. de sôro humano estéril. Esperar 10';

- colocar em 4 tubos $0,5 \mathrm{ml}$. do inoculum de Stafilococos Aureus;

- após 10' de contato do cloreto de Benzalcônio com o sôro humano estéril, transferir uma alçada para o tubo com Escherichia Coli;

- nos intervalos de 30', 1', 2', 5', e 10' retirar uma alçada para o meio de cultura;

- a prova acima foi repetida com o inoculum de Stafilococos Aureus, porém no seguinte tempo de contato: 30', 1 hora, 2 horas;

- incubar por uma semana a $37^{\circ} \mathrm{C}$. 
6:1.6. Resultado observado: ação bactericida evidenciada.

6.2 Cloreto de Benzalcônio a $1 \%$ em presença de fluidos biológicos (com uso de placas de Petri):

\subsubsection{Finalidade:}

Esste método foi elaborado para testar a ação do cloreto de Benzalcônio a $1 \%$ em presença de fluidos biológicos (sôro humano), com uso de placas de Petri.

\subsubsection{Microorganismos usados e meio de cultura:}

A. Microorganismos usados:

- Stafilococos Aureus - 209 (1209).

B. Meio de cultura:

- Penasssay Seed Agar (Difco).

\subsubsection{Material necessário:}

- 2 tubos $25 \times 200 \mathrm{~mm}$.

- 3 placas de Petri.

- 1 pinça

- sôro humano (filtrado em membrana Millig G.S.)

- discos de papel filtro Whatnus ( $3 \mathrm{~mm}$.)

- solução salina de $\mathrm{NaC} 10,9 \%$.

\subsubsection{Preparo do Inoculum:}

Preparar uma suspensão de uma cultura de 24 horas de Stafilococos Aureus, com $10 \mathrm{ml}$. de solução salina. Pipetar $1 \mathrm{ml}$. dessa suspensão e transferir para $9 \mathrm{ml}$. de solução salina. Em seguida transferir para o meio de cultura Penassay Seed Agar na proporção de $1 / 100$. Vazar $20 \mathrm{ml}$. do meio inoculado para as placas de Petri e deixar solidificar.

Transferir os discos que estão em contato com a solução de cloreto de Benzalcônio para as placas de Petri acima mencionadas.

Incubar por uma semana a $37^{\circ} \mathrm{C}$.

Se o sôro humano inativar a ação do desinfetante, haverá um crescimento de diâmetro maior ao redor dos discos contidos nas placas. 


\section{CRESCIMENTO OBSERVADO EM PLACAS COM DISCOS CONTENDO CLORETO DE BENZALCÔNIO COM E SEM SÔRO HUMANO.}

CLORETO DE BENZALCÔNIO A $1 \%$
CLORETO DE BENZALCÖNIO A $1 \%$. SÔROHUMANO

$\begin{array}{lllll}\text { DISCO } & 1 & 2,12 \mathrm{~mm} . & \text { DISCO } 1 & 2,445 \mathrm{~mm} \\ \text { DISCO } & 2 & 2,375 \mathrm{~mm} . & \text { DISCO } 2 & 2,045 \mathrm{~mm} \\ \text { DISCO } 3 & 2,28 \mathrm{~mm} . & \text { DISCO } 3 & 1,596 \mathrm{~mm} \\ \text { DISCO } & 4 & 2,253 \mathrm{~mm} . & \text { DISCO } 4 & 2,042 \mathrm{~mm}\end{array}$

\section{CONCLUSÃO:}

Ante os resultados obtidos podemos concluir que o Cloreto de Benzalcônio não tem ação esporicida quando usado em concentrações as mais diversas $(1 \%, 00,1 \%, 5 \%)$. E um agente bacteriostático e seu uso deve ser restringido a desinfecção e antissepsia.

\section{B I B L I O G R A F I A}

1. PERKINS, John J. - Principles and Methods of Sterilization. Charles C. Thomas - Publisher U.S.A. - 1956.

2. LAWRENCE, Carl A. - BLOCK, Seymour S. - Desinfection, Sterilization, and Preservation. Lea Febiger. Philadelphia 1968.

3. CORBET, Charles Edward. Elementos de Farmacodinâmica S.P. Artes Médicas, 1966.

4. REDDISH, G. F. - Antisseptic desinfectants fungicides and Chemical and physical Sterilization - Philadelphia Febiger, 1954.

5. ZINSSER, Hans - BAYNE-JONES, Stanhope, Tratado de Racteriologia - Rio de Janeiro - 1947 - 8. ${ }^{\circ}$ ed. Imprensa Nacional - p. 107.

6. ZOGRAFI, George, Platel R. Praful - WEINER, D. Norman - Interactions between brange II and selected long chain Quaternary Ammonium Salts. Journal Of Pharmaceutical Sciences - V 53 p 544549-964

7. STAINIER Y. Roger, DOUDOROFF, Michael - ADELBEGA EDWAREL - Mundo dos Micróbios. Editôra Edgar Blucher Ltda. USP 1969.

8. Evaluated by A.M.A. Council on Drugs - New and Nonofficial Drugs - 1964 .

9. BIER, Otto - Bacteriologia e Imunologia - Ed. Melhoramentos $13 .^{\mathrm{a}}$ ed. -1966.

10. COLLINS C. H. - Microbiological Methods London Butterworths 1964. 